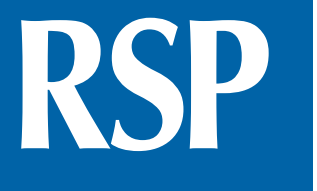

http://www.rsp.fsp.usp.br/
Revista de Saúde Pública

\title{
Ordinance 3992/2017: challenges and advances for resource management in the Brazilian Unified Health System (SUS)
}

\author{
Blenda Leite Saturnino Pereira' \\ iD, Antonio Carlos Rosa de Oliveira Junior" \\ Faleiros $^{1}$ iD \\ I Conselho Nacional de Secretarias Municipais de Saúde. Brasília, DF, Brasil \\ "Conselho Nacional de Secretarias de Saúde. Brasília, DF, Brasil
}

iD, Daniel Resende

\section{ABSTRACT}

To advance in order to overcome the challenge of enabling greater autonomy in the use of financial resources in the Unified Health System (SUS), system managers agreed that transfers from the Union to other federated entities will be carried out through a financial investment account and a costing account. Over the past few years, states and municipalities managed more than 34,000 bank accounts dedicated to the Union's on-lendings, in which balance exceeded $\mathrm{R} \$ 8$ billion. However, from 2018, Ordinance 3,992/2017 unequivocally separated the budget flow from the financial flow, and the fund-to-fund transfers started to be carried out in only 11,190 bank accounts. Since then, managers have had financial autonomy in the management of financial resources received from the Union, if in accordance with the parameters established in their respective budget items at the end of each fiscal year.

DESCRIPTORS: Unified Health System, economics. Financial Resources in Health, organization \& administration. Healthcare Financing.

Correspondence:

Blenda Leite Saturnino Pereira

Conselho Nacional de Secretárias

Municipais de Saúde

Esplanada dos Ministérios, Bloco G,

Edifício Anexo sala 144b

70058-900 Brasília, DF, Brasil

E-mail: blspereira@gmail.com

Received: Jul 4, 2018

Approved: Nov 11, 2018

How to cite: Pereira BLS,

Oliveira Junior ACR, Faleiros DR.

Ordinance 3992/2017: challenges

and advances for resource

management in the Brazilian

Unified Health System (SUS). Rev

Saude Publica. 2019;53:58.

Copyright: This is an open-access article distributed under the terms of the Creative Commons Attribution License, which permits unrestricted use, distribution, and reproduction in any medium, provided that the original author and source are credited. 


\section{INTRODUCTION}

The Unified Health System (SUS), established to guarantee health as a social right to all citizens, and a duty of the Brazilian State, has as a funder the federated entities: Union, States, Federal District and municipalities. The adequate allocation of resources is essential in the financing process, in order to provide economic and financial sustainability to all management spheres responsible for guaranteeing the right to health ${ }^{1}$. Despite the implementation of public health actions and services (ASPS), the adequate and necessary financing and the necessary autonomy in the use of the financial resources received from other federated entities have not been a reality for municipal management ${ }^{2}$. It is highlighted that, in Arretche's view ${ }^{3}$, autonomy is an indispensable condition for managers to exercise innovation and creativity to execute these actions.

In the past years, the values dedicated to the ASPS, transferred by the Union to the subnational entities, have registered less representation in relation to the total expenditures of the Ministry of Health. In 2014, on-lendings reached $67.0 \%$ of total expenditures of the healthcare sector, compared to 60.1\% in 2017. Based on 2014, between 2015 and 2017, because of the increase of Union expenses, states and municipalities no longer received R $\$ 14.9$ billion (Table) .

In 2017, the Tripartite Interagency Committee of SUS agreed that transfers of resources from the Union, starting in 2018, will be carried out through an account for the financial movement of investment resources and another account for the movement of resources destined to the costs of $\mathrm{ASPS}^{4}$. The purpose of this agreement was to overcome the challenge of promoting greater autonomy to subnational entities ${ }^{5}$ in the use of financial resources, as well as to mitigate the effects of the system's gross under-funding.

By 2018, funds allocated to the costing of ASPS were transferred through five financing blocks, passed through hundreds of labels. Therefore, the financial flow was linked to the budget flow, which compromised the autonomy of financial management of subnational entities. Survey conducted by the National Health Fund (FNS - Fundo Nacional de Saúde) identified more than 800 different on-lendings to attend actions, programs, incentives and strategies of the Ministry of Health. This practice, known as "labeling" or "boxes", was used to segregate resources in specific subaccounts, which made financial management difficult and induced the accumulation of balances ${ }^{6}$.

To give normative support to the agreement of the SUS managers, Ordinance 3,992/2017 which alters the Consolidation Ordinance No. $6 / \mathrm{GM} / \mathrm{MS} / 2017^{8}$, was published to provide for the financing and transfer of federal resources to ASPS to other federated entities, in the fund-by-fund modality, in accordance with Article 18 of Complementary Law 141/2012 .

${ }^{a} \mathrm{R} \$ 1.00=$ USD3.8658, according to Banco Central do Brasil (Brazilian Central Bank) on June 11, 2019.

\section{Advances and Challenges}

Ordinance 3,992/2017 modified the understanding of revoked Ordinance $204 / 2007^{10}$ on the transfer of federal resources that took place as six financing blocks. However, the changes

Table. Public expenditure on public health actions and services and representativeness of the National Health Fund transfers (2014 to 2017).

\begin{tabular}{|c|c|c|c|c|c|c|c|c|c|}
\hline \multirow[b]{2}{*}{ Year } & \multicolumn{3}{|c|}{ Federal } & \multicolumn{3}{|c|}{ State } & \multicolumn{3}{|c|}{ Municipal } \\
\hline & $\begin{array}{c}\text { Expenses } \\
{\text { (thousand } \mathbf{R} \$)^{a, c}}^{-1}\end{array}$ & 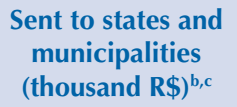 & $\%$ & $\begin{array}{c}\text { Expenses } \\
(\text { thousand } \mathbf{R} \$)^{\mathrm{a}, \mathrm{c}}\end{array}$ & $\begin{array}{l}\text { Received from the } \\
\text { Union } \\
\text { (thousand } \mathbf{R} \$)^{\mathbf{b}, \mathrm{c}}\end{array}$ & $\%$ & $\begin{array}{c}\text { Expenses } \\
(\text { thousand } \mathbf{R} \$)^{\mathrm{a}, \mathrm{c}}\end{array}$ & $\begin{array}{l}\text { Received from the } \\
\text { Union } \\
\text { (thousand } \mathbf{R} \$)^{\mathbf{b}, \mathrm{c}}\end{array}$ & $\%$ \\
\hline 2014 & $115,076,875$ & $77,139,340$ & 67.0 & $71,758,773$ & $21,580,321$ & 30.1 & $84,375,761$ & $55,559,019$ & 65.8 \\
\hline 2015 & $113,409,395$ & $74,090,892$ & 65.3 & $68,620,617$ & $20,132,504$ & 29.3 & $81,862,935$ & $53,958,390$ & 65.9 \\
\hline 2016 & $112,550,592$ & $71,028,183$ & 63.1 & $67,055,831$ & $18,544,164$ & 27.7 & $83,168,055$ & $52,484,020$ & 63.1 \\
\hline 2017 & $118,780,816$ & $71,349,729$ & 60.1 & $70,426,625$ & $18,742,053$ & 26.6 & $84,251,486$ & $52,607,676$ & 62.4 \\
\hline
\end{tabular}

Source: aSistema de Informações sobre Orçamentos Públicos em Saúde and ${ }^{b}$ National Health Fund. Own elaboration.

c Monetary values in thousands of Reais updated to July 2018 according to the National Consumer Price Index of the Brazilian Institute of Geography and Statistics $(\mathrm{R} \$ 1.25(2014)=\mathrm{R} \$ 1.13(2015)=\mathrm{R} \$ 1.06(2016)=\mathrm{R} \$ 1.03(2017)=\mathrm{R} \$ 1.00$ (July 2018). 
brought about by the new rule raised doubts and misunderstandings about its operational form. For many years, the repealed standard has led managers to implement financial resources from the Union tied to the respective blocks or to specific budget linkages.

The execution of these resources connected to the budget of the Union, and not to the needs of local financial flow, crystallized in the municipal management, starting to compromise the autonomy of local management. Financial execution was tied to Union programs, actions and budget plans, or even a misconception that it would be easier to manage federal resources in separate financial accounts from other transfers. Consequently, innumerable bank accounts have been opened in order to mismanagely facilitate the management of the federal funds received. Between 2014 and 2017, states and Federal District managed more than 560 accounts, and the municipalities more than 34 thousand. In 2018, after the entry into force of Ordinance 3,992/2017, there are only 54 accounts in the states and 11,136 in the municipalities: one for investment on-lending and one for costing (Figure 1).

The unnecessary links induced managers and even auditors to misunderstand the analysis of tracking financial disbursements. Bank account data were used as an instrument to control budget actions, avoiding linkage to the real instruments of planning and monitoring, these ones of unequivocal accountability. More than that, many managers stopped using the received resources, to the point of annually recording billions of Reais accumulated in

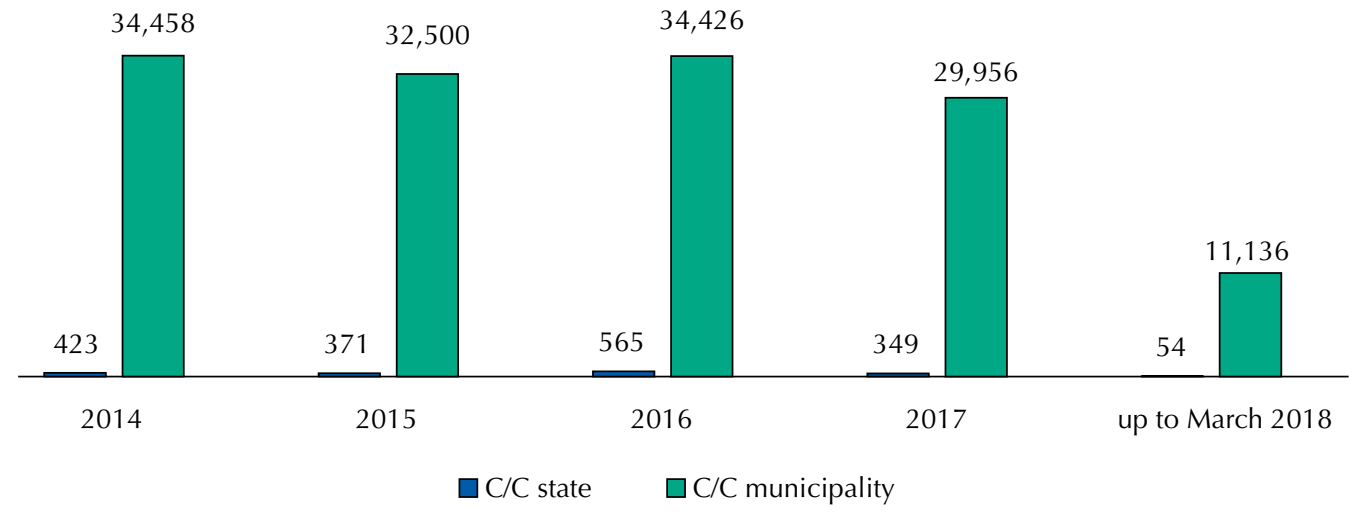

Source: National Health Fund. Own elaboration. C/C: checking account

Figure 1. Number of checking accounts by states and municipalities that received fund-to-fund resources transfers from the Ministry of Health (2014 to March 2018).

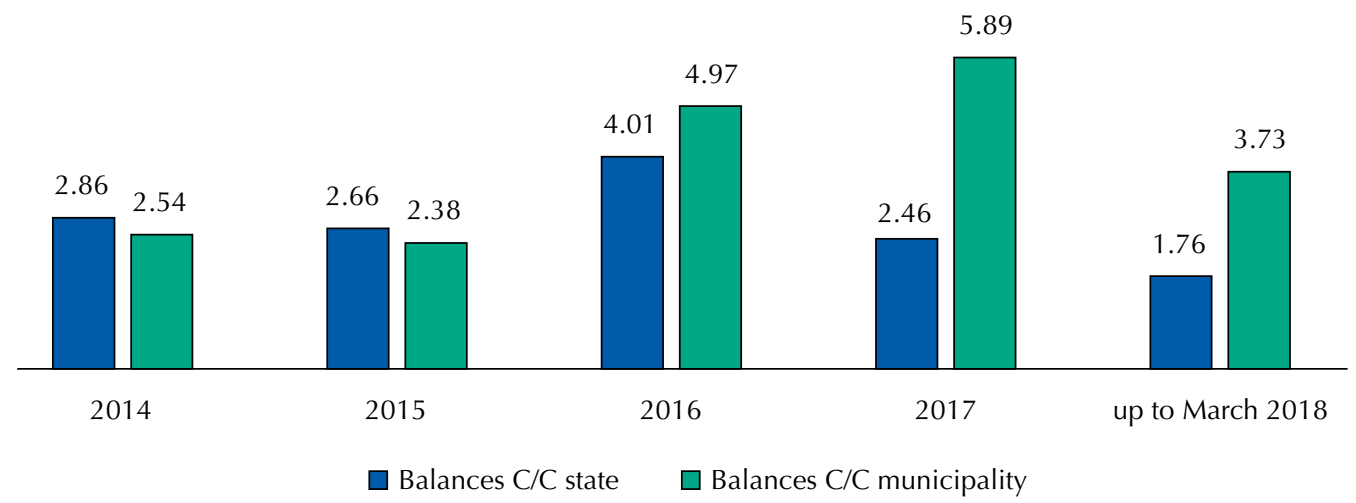

Source: National Health Fund. Own elaboration. C/C: checking account

Figure 2. Total value of bank balances in checking accounts by states and municipalities that received fund-to-fund resources transfers from the Ministry of Health in billions of Reais (2014 to March 2018). 
thousands of accounts. As a result, the values have accumulated in recent years, reaching, in 2017, more than $\mathrm{R} \$ 8.6$ billion in updated values for June 2018 (Figure 2).

This diagnosis was possible due to Complementary Law 141/2012, which determines that the resources of the Union transferred to the other entities of the Federation must be moved until their final destination in specific accounts, kept in a federal official financial institution. On the other hand, the same legislation guarantees the delivery of such resources to confirmation, by the sub-national entity, the establishment and functioning of the Health Fund and the Health Council, as well as the preparation of the respective health plans. The health funds are established by laws and maintained by the direct administration of the entities, being considered budgetary units and resource managers.

In turn, Law 8,080/1990 11 regulated the ASPS, establishing that federated entities, among other duties, prepare and periodically update the health plans and prepare the annual budget proposal, in accordance with the respective plan. It should be noted that the agreements made within the bipartite and tripartite committees reflect the municipal and regional needs within the established conditions, respecting the geographical and epidemiological specificities and the installed capacity, among others. Therefore, such agreements must be considered as part of a process that leads to the upward planning of the system, a challenge that is set to be one of the major ones for SUS ${ }^{12}$ consolidation.

Still as the responsibility of the federated entities, it is mentioned the elaboration of the Annual Health Schedule (PAS - Programação Anual de Saúde), which dialogues directly with the Annual Budgetary Law (LOA - Lei Orçamentária Anual). The PAS should contain, in a systematic way, the actions, the financial resources and other elements that contribute to achieve the objectives and the fulfillment of the plan goals, besides the annual goals for each defined action and the indicators used in the monitoring and evaluation of its execution. This whole process must be linked to the public budget, which is an instrument for planning and executing public finances. The budget as a planning instrument governs the revenue forecasting and the expenditure setting and follows strict drafting standards, becoming a legal instrument for each financial year.

The new regulation came to comply with the normative planning of the SUS regarding federal transfers without changing the calculation methodology for distribution of resources. The new rule does not create the methodology for distribution of federal resources disciplined by Article 17 Complementary Law 141/2012, it only disciplines the organization of federal transfers in two financing blocks - the Block of Costs of Health Actions and Services, and the Block of Investment of the Health Services Network - which will be transferred by the FNS, according to the existing allocation criteria.

In this context, authorized by a previous rule, the governmental expenditure of the federated entities must obey the rules imposed for its execution, that is, the requirement of resource binding is maintained. Thus, Ordinance 3,932/2017 establishes that, at the end of each fiscal year, the federal resources transferred to the subnational entities must meet the purposes defined in the Work Program of the General Union Budget, which originated the on-lendings carried out, as well as those established in the health plan and in the Annual Local Health Program.

The link between the purpose of the programs that finance the federal transfers and the application of resources by the federated entities originates in a constitutional provision (Article 167, section VI), which also prohibits "the transposition, relocation or transfer of resources of a programmed category to another or from one administrative body to another, without prior legislative authorization" (section VI). Thus, it is not possible for the Executive Power to approve the application of financial resources by another federal entity for a purpose other than that specified in the federal LOA that authorized the expense. At federal level, execution is already considered to have been effected through the transfer. Only through legislative authorization - in this case, a change of the LOA by the National Congress - it is 
possible to change the purpose of the expenditure foreseen in the approved capital grant for a specific budget schedule. The linking of the federal pass-through originated from a budgetary program links the purpose to this schedueling and thus corroborates the established by Complementary Law $101 / 2000^{13}$ regarding the continuity of the attachment, even in the exercise subsequent to the resource admission to the local health fund.

Failure to comply with the provisions of budgetary and financial legislation, with the consequent misuse of funds in the application of resources, implies that the manager is convicted of administrative misconduct, as provided for in Law 8,429/1992 ${ }^{14}$. In this case, the person responsible for the offending act shall be subjected to penalties imposed irrespective of the criminal, civil and administrative penalties provided for in the specific legislation. The public administrator is responsible for the execution of the budget according to the conduct regulated by Complementary Law 101/2000, which establishes public finance rules aimed at responsibility in fiscal management. In case of administrative misconduct, the manager will face the penalties provided for in Law $10,028 / 2000^{15}$, which deals with crimes in public finances. Thus, at the end of each fiscal year, the financial execution should be completely adequate to the budget execution, obeying the one disciplined by Law 4,320/1964 ${ }^{16}$.

Ordinace 3,992/2017 unequivocally separates the budget flow from the financial flow. However, as disciplined by Law 4,320/64, at the end of each fiscal year, what is established by the budget item shall prevail. After all, the public budget is an instrument that presents to the society the intention of the manager to carry out actions throughout the year, which should be reflected in the annual management report, subsequently evaluated and approved by the local Health Board.

Therefore, it is necessary to clarify that the challenge of change, which now comes with the unification of bank current accounts, brings in its overcoming process the strengthening of planning instruments and, consequently, the management of SUS. These instruments are fundamental to the health system and essential to implement and consolidate, definitively, the tools that enable following, monitoring and evaluation actions, so commonly mentioned, but little used and appreciated over the past years. The changes arising from Ordinance No. 3,992/2017 aim to provide a better, more effective and safe application of the resources received by the Health Funds against the responsibilities of the health manager, attributed by Law 8,080/90.

\section{CONCLUSION}

Duarte et al. ${ }^{17}$ report that some authors point out a possible excess of autonomy in municipal management presents itself as responsible for the fragmentation of SUS, opposing to others that identify limitations of this same autonomy when it comes to the parameters established for transfers of federal resources, mainly in the sphere of municipal management.

Ordinance 3,992/2017 did not change any linkage of financial resources destined to SUS actions and programs. The standard innovated by allowing flexibility in the financial flow of public health management, allowing the managers of the subnational spheres more autonomy in the management of financial resources received from the Union to carry out the actions agreed and programmed.

As a natural consequence of this change, the challenge of invigorating the elaboration processes, monitoring and evaluation of planning and budget instruments arises. All this process has been improving and strengthening the management and public health policy in the country. This, in turn, makes it possible for the financial resources transferred by the Union to subnational entities to be used more efficiently in the implementation of the ASPS.

It is undeniable that Ordinance 3,992/2017 contributed to overcoming the challenge of guaranteeing more autonomy to subnational entities. However, it is still far from overcoming 
the greater challenge: to provide the autonomy to use federal resources in order to provide means that meet the regional health needs of the population, according to local plans agreed upon and established as a guideline of Law 8,080/90.

\section{REFERENCES}

1. Santos L, Mendes AN. Notas técnico-jurídicas sobre critérios e metodologia de rateio dos recursos federais para os estados e municípios no SUS. BDM Bol Direito Municipal. 2014;30(9):647-64.

2. Silva SF, Souza NM, Barreto JOM. Fronteiras da autonomia da gestão local de saúde: inovação, criatividade e tomada de decisão informada por evidências. Cienc Saude Coletiva. 2014;19(11):4427-38. https://doi.org/10.1590/1413-812320141911.16612013

3. Arretche M. Financiamento federal e gestão local de políticas sociais: o difícil equilíbrio entre regulação, responsabilidade e autonomia. Cienc Saude Coletiva. 2003;8(2):331-45. https://doi.org/10.1590/S1413-81232003000200002

4. Ministério da Saúde (BR). Portaria No 1.091, de 27 de abril de 2017. Institui Grupo de Trabalho Tripartite para propor normas e procedimentos voltados ao fortalecimento do processo de planejamento e de transferência dos recursos federais para o financiamento das ações e serviços públicos de saúde no âmbito do Sistema Único de Saúde. Brasília, DF; 2017 [cited 2018 Jan 5]. Available from: http//bvsms.saude.gov.br/bvs/saudelegis/gm/2017/prt1091_02_05_2017.htm

5. Carvalho G. A inconstitucional administração pós-constitucional do SUS através de normas operacionais. Cienc Saude Coletiva. 2001;6(2):435-44. https://doi.org/10.1590/S1413-81232001000200012

6. Rosendo AB. Financiamento da Saúde a partir da Portaria no 3992/2017, do Ministério da Saúde - 07/06/2018. Brasília, DF; 2018 [cited 2018 Jun 21]. Available from: http://www2.camara.leg. br/atividade-legislativa/comissoes/comissoes-permanentes/cft/audiencias-publicas/audienciaspublicas-2018/ApresentaoMinistriodaSade.pdf

7. Ministério da Saúde (BR). Portaria No 3.992, de 28 de dezembro de 2017. Altera a Portaria de Consolidação ${ }^{\circ}$ 6/GM/MS, de 28 de setembro de 2017, para dispor sobre o financiamento e a transferência dos recursos federais para as ações e os serviços públicos de saúde do Sistema Único de Saúde. Brasília, DF; 2017 [cited 2018 May 2]. Available from: http://bvsms.saude.gov. br/bvs/saudelegis/gm/2017/prt3992_28_12_2017.html

8. Ministério da Saúde (BR). Portaria Nº 6, de 28 de setembro de 2017. Consolidação das normas sobre o financiamento e a transferência dos recursos federais para as ações e os serviços de saúde do Sistema Único de Saúde. Brasília, DF; 2017 [cited 2018 May 13]. Available from: http://bvsms.saude.gov.br/bvs/saudelegis/gm/2017/prc0006_03_10_2017.html

9. Brasil. Lei Complementar $N^{\circ} 141$, de 13 de janeiro de 2012. Regulamenta o $\S 3^{\circ}$ do art. 198 da Constituição Federal para dispor sobre os valores mínimos a serem aplicados anualmente pela União, Estados, Distrito Federal e Municípios em ações e serviços públicos de saúde; estabelece os critérios de rateio dos recursos de transferências para a saúde e as normas de fiscalização, avaliação e controle das despesas com saúde nas três esferas de governo; revoga dispositivos das Leis nos 8.080, de 19 de setembro de 1990, e 8.689, de 27 de julho de 1993; e dá outras providências. Brasília, DF; 2012 [cited 2018 May 11]. Available from: <http://www.planalto.gov. br/ccivil_03/leis/LCP/Lcp141.htm

10. Ministério da Saúde (BR). Portaria No 204, de 29 de janeiro de 2007. Regulamenta o financiamento e a transferência dos recursos federais para as ações e os serviços de saúde, na forma de blocos de financiamento, com o respectivo monitoramento e controle. Brasília, DF; 2007 [cited 2018 May 2]. Available from: <http://bvsms.saude.gov.br/bvs/saudelegis/gm/2007/ prt0204_29_01_2007_comp.html

11. Brasil. Lei $n^{\circ} 8.080$, de 19 de setembro de 1990. Dispõe sobre as condições para a promoção, proteção e recuperação da saúde, a organização e o funcionamento dos serviços correspondentes e dá outras providências. Brasília, DF; 1990 [cited 2018 Apr 12]. Available from: http://www.planalto.gov.br/ccivil_03/leis/L8080.htm

12. Vieira FS. Avanços e desafios do planejamento no Sistema Único de Saúde. Cienc Saude Coletiva. 2009;14 Supl 1:1565-77. https://doi.org/10.1590/S1413-81232009000800030

13. Brasil. Lei complementar $N^{\circ} 101$, de 4 de maio de 2000. Estabelece normas de finanças públicas voltadas para a responsabilidade na gestão fiscal e dá outras providências. Brasília, 
DF; 2000 [cited 2018 Jun 5]. Available from: http://www.planalto.gov.br/ccivil_03/Leis/lcp/ Lcp101.htm

14. Brasil. Lei № 8.429, de 2 de junho de 1992. Dispõe sobre as sanções aplicáveis aos agentes públicos nos casos de enriquecimento ilícito no exercício de mandato, cargo, emprego ou função na administração pública direta, indireta ou fundacional e dá outras providências. Brasília, DF; 1992. Available from: http://www.planalto.gov.br/ccivil_03/LEIS/L8429.htm

15. Brasil. Lei $\mathrm{N}^{\circ}$ 10.028, de 19 de outubro de 2000. Altera o Decreto-Lei no 2.848, de 7 de dezembro de 1940 - Código Penal, a Lei no 1.079, de 10 de abril de 1950, e o Decreto-Lei no 201, de 27 de fevereiro de 1967. Brasília, DF; 2000 [cited 2018 Nov 2]. Available from: http:// www.planalto.gov.br/ccivil_03/LEIS/L10028.htm

16. Brasil. Lei $\mathrm{n}^{\circ} 4.320$, de 17 de março de 1964. Estatui Normas Gerais de Direito Financeiro para elaboração e controle dos orçamentos e balanços da União, dos Estados, dos Municípios e do Distrito Federal. Brasília, DF; 1964 [cited 2018 Nov 2]. Available from: http://www.planalto.gov. br/ccivil_03/LEIS/L4320.htm

17. Duarte LS, Mendes AN, Louvison MCP. O processo de regionalização do SUS e a autonomia municipal no uso dos recursos financeiros: uma análise do estado de São Paulo (2009-2014). Saude Debate. 2018;42(116):25-37. https://doi.org/10.1590/0103-1104201811602

Authors' Contributions: Conception and planning of the study: BLSP, ACROJ, DRF. Data collection, analysis and interpretation: BLSP, ACROJ, DRF. Elaboration or revision of the manuscript: BLSP, ACROJ, DRF. Final version approval: BLSP, ACROJ, DRF. Public responsibility for the content of the article: BLSP, ACROJ, DRF.

Conflict of Interest: The authors declare no conflicts of interest. 